\title{
ANALYSIS OF NEUROPEPTIDE GENE EXPRESSION BY TRANSFECTION OF DNA INTO CELL LINES
}

\author{
Kevin M. Walton and Robert P. Rehfuss \\ Department of Biological Chemistry, University of Michigan School of Medicine, Ann Arbor, Michigan \\ 48109, and Laboratory of Molecular Endocrinology, Royal Victoria Hospital, \\ Montreal, Quebec H3A 1A1, Canada
}

\begin{abstract}
SUMmARY: The transcriptional regulation of neuropeptide genes by cAMP is often directed by a cAMP responsive enhancer (CRE) upstream to the promoter of the genes. The identity of the CRE was determined by transient transfection experiments and has the consensus sequence of 5'-TGACGTCA-3'. A large family of transcription factors have been identified which recognize the CRE. Transient transfection assays that employed expression of these factors driven by viral promoters have determined they can transactivate the neuropeptide gene promoters. Because of the large number of factors that have been identified as being able to recognize the CRE, it has been difficult to determine which factors mediate in vivo the transactivation of a particular CRE. Using a dominant negative mutant of one of these factors, CREB, it has been determined that both CREB as well as other factors which do not interact with CREB may mediate the cAMP response of the somatostatin gene.
\end{abstract}

Key words: cAMP; CREB; CRE; somatostatin; transcription.

\section{INTRODUCTION}

Several neuropeptides increase in expression in response to increased levels of cellular cAMP $(10,14,23)$. The mechanism behind this induction remained unclear until the cloning of the genes for these neuropeptides. It has since become apparent that comparable elements upstream to the promoters in these genes control their response to cAMP $(4,24,28)$. Extensive study of these cAMP-responsive enhancers (CREs) revealed that even though the sequences are similar there are significant functional differences among them (7). These variations in the basic motif are likely to confer to the enhancer distinct affinities to the numerous transcription factors that can recognize the CRE, yielding different transcriptional responses to cellular stimuli. The first cloned CRE-binding protein, CREB, was isolated using the CRE from the somatostatin promoter as a probe $(12,15)$. CREB falls into the class of basic region leucine zipper (bZIP) transcription factors. These factors have a transactivation domain at the amino-terminus and domains that function in the dimerization of the protein and the recognition of the DNA enhancer sequence at the carboxy-terminus. Since the original isolation of CREB, a large family of related proteins have been identified that recognize the CRE and are also bZIP proteins $(13,16,21)$. Although all of these factors can dimerize with themselves (homodimers), some are also able to form dimers with each other (heterodimers). Thus, the complex activities of the CRE sequences are matched by the large number of factors, both as homodimers and heterodimers, which can recognize them.

Experiments to determine the transcriptional characteristics of the different CREs, the ability of each factor to transactivate the different CREs, and the mechanism behind the transactivation have been performed both in vitro with cell-free systems and in vivo by transfection into appropriate cell lines. Although cell-free systems have produced significant results, they are not able to mimic the complex signal transduction pathways present in whole cells. Transfection of DNA constructs into cell lines has been used to a much greater extent in determining the functional characteristics of the CREs and CRE-binding proteins.

Analysis of the CRE. The CRE was first identified in the genes for phosphoenolpyruvate carboxykinase $(26,31)$ and the neuropeptides proenkephalin (4) and somatostatin (24). The minimal sequence required to maintain the cAMP response was determined by transfection of constructs consisting of the upstream regions placed $5^{\prime}$ to a minimal viral promoter controlling the expression of a reporter gene, chloramphenicol acetyltransferase (CAT). Deletional analysis of the upstream regions of these and other genes identified an eight base pair (bp) consensus sequence, $5^{\prime}$-TGACGTCA-3'. Experiments using the endogenous promoter of somatostatin revealed that the CRE also acts as a basal level activator. Unstimulated expression of the somatostatin promoter decreases 10 -fold upon deletion of the CRE (2).

The sequence of the minimal CRE varies among cyclic 
AMP (cAMP)-responsive genes. A number of genes have the perfect palindromic sequence, 5'-TGACGTCA-3' $(24,27,30)$. However, other genes only have a single copy of the inverted repeat, $5^{\prime}$-CGTCA-3' $(4,26)$. Still another has the inverted repeats, but they are separated by a number of nucleotides (28). The importance of the inverted repeat vs. the single copy CRE is currently unclear. However, point mutations within the palindromic CRE indicate that the two copies of the repeat are not equivalent. In the glycoprotein $\alpha$-subunit gene, both mutant sequences $5^{\prime}$ AGACGTCA-3' and 5'-TGACGTCT-3' result in reduced basal activities (8). However, the $5^{\prime}$ mutation still elicits a cAMP response whereas the $3^{\prime}$ mutation is insensitive to cAMP.

The activity of a CRE sequence depends on a number of parameters, including the sequences adjacent to the CRE, the promoter to which the CRE is attached, and the cell type in which the activity is being assayed. Each of these has been analyzed by transfection experiments. Placement of CREs from a number of different genes on an identical promoter has revealed significant functional differences. The consensus CRE sites and adjacent sequences from the glucagon $(-290$ to -268$)$, parathyroid hormone ( -79 to -62$)$, glycoprotein $\alpha$-subunit ( -128 to $-111)$, and somatostatin $(-56$ to -33$)$ genes were placed upstream to the glycoprotein $\alpha$-subunit promoter deleted of all endogenous upstream regulatory sequences (7). Even though each of these CREs includes the identical eight bp palindrome, they conferred different basal and stimulated activities on the promoter. The glucagon and parathyroid constructs increased basal activity by only 1.5-fold and produced an 8-fold increase in response to cAMP. In contrast, the $\alpha$-subunit and somatostatin CREs produced basal activities of 7- to 10 -fold and stimulated responses of 20 -fold. Thus, the activity of a CRE sequence is modulated by sequences immediately adjacent to it.

Both promoter effects and cell-type effects were identified using the CRE from the glycoprotein $\alpha$-subunit gene (17). The $\alpha$-subunit CRE has no effect on the basal activity of the minimal $\alpha$-subunit promoter when expressed in INRI-G9 cells, a rat islet cell line. However, when placed in front of the minimal somatostatin promoter, basal activity increased by 36 -fold. This large difference in basal activity, although directed by the promoter, is dependent on the cell line used. When these constructs are transfected into JEG-3 cells, a human placental cell line, both produce a 2.5- to 10-fold increase in basal activity.

In addition to the interactions between cAMP-responsive elements and their promoters as described above, another level of complexity is added by the interaction between CREs and adjacent enhancer sequences. The CRE located in the glycoprotein $\alpha$-subunit gene interacts with cis-acting sequences upstream to the enhancer. This CRE consists of two identical 18 bp repeats in which reside a perfect $8 \mathrm{bp}$ CRE. Immediately upstream to these CREs lies a tissue-specific enhancer which acts to increase both basal and stimulated activity by 3 - to 5 -fold and is completely dependent on the CRE for activity $(6,17)$.

$C R E$-binding proteins. An explanation for the complex pattern of responses among individual CREs is that a variety of different CRE-binding proteins exist, each with its own unique affinity and activity. The initial isolation of some of these proteins has confirmed this hypothesis and has identified a complex super-family of genes that encode CRE-binding proteins. All of these factors isolated to date share the common structural elements of a carboxyterminal basic DNA binding region and a leucine zipper motif (18). Dimerization of these factors is mediated by the leucine zipper which consists of four to five leucines separated from each other by seven amino acids. The zippers interact with each other to form a coiled-coil structure (25). The primary sequence of amino acids in the basic DNA binding domain varies slightly among the different CRE binding proteins, with greater than $50 \%$ of the residues present being either lysine or arginine. These factors bind to DNA only as dimers, and each can form a homodimer. Several factors have been shown to form heterodimers. The factors CRE-BP1 and CRE-BP2, for instance, readily form heterodimers with c-jun, a transcription factor in the protein kinase $\mathrm{C}$ signal transduction pathway $(16,20)$. This may represent a mechanism for crosstalk between the kinase $\mathrm{C}$ and kinase A pathways.

In addition to the DNA-binding and leucine zipper domains, all of the CRE binding proteins have amino-terminal regions which are involved in transcriptional activation. Although they are poorly conserved among the class as a whole, they generally have consensus phosphorylation sites for a number of different protein kinases. Transfection experiments have been used extensively to analyze the role of phosphorylation in the mechanism of transactivation by CREB. In some of these experiments, the F9 cell line has been used because it has little endogenous activity on the CRE. Here, the reporter gene containing a CRE sequence upstream to the promoter is cotransfected with a CDNA for CREB driven by a viral promoter and with the cDNA for protein kinase A (PKA) also driven by a viral promoter. The CREB cDNA can be altered by standard molecular biological techniques to produce proteins with point mutations or with entire regions deleted. An alternative technique has been used which involves creating a fusion protein between CREB and the DNA binding domain from the yeast transcription factor, GAL4. In this case, the GAL4 enhancer is placed upstream to the reporter gene. The strength of this technique is that cells with an endogenous cAMP response can be used to analyze CREB mutants because only the CREB fusion proteins can bind to the reporter construct and stimulate transactivation. Experiments using these techniques showed that substitution of the serine in the PKA site with either alanine, glutamic acid, or aspartic acid severely inhibited the ability of CREB to activate transcription $(11,19)$. The phosphorylation of CREB by PKA is, however, not sufficient to produce a fully active transcription factor. Additional serine-rich sequences near the kinase A site are also necessary for activity (19). Phosphopeptide mapping of mutant CREB proteins expressed in JEG-3 cells indicated that these "phosphorylation boxes" are modified subsequent to the primary phosphorylation by PKA. Two of these elements, PDE 1 and PDE 2, are 
absolutely required for complete activity. The observation that CREB requires multiple phosphorylations to be fully active implies that several signaling pathways acting through different kinases could control the activity of CREB.

Because cells express multiple CRE binding proteins, it has been difficult to determine exactly which factors are involved in the transactivation of any particular CRE. One method to approach this question would be to eliminate particular factors and assess the remaining cAMP response. We have been able to do this by using a dominant repressor of CREB. This factor, KCREB, is a mutated form of CREB that has a single point mutation in the DNA-binding domain. This mutation not only blocks the ability of the KCREB homodimer to bind DNA, but also inhibits the ability of CREB to bind DNA when in a heterodimer with KCREB (29). Transfection experiments showed that KCREB will block CREB when both are expressed in the $\mathrm{F} 9$ cell line. KCREB was then expressed in the CA-77 cell line which endogenously expresses CREB and produces a strong CAMP-induced expression of the somatostatin promoter. These experiments revealed that the somatostatin CRE may be transactivated both by CREB and by other factors that do not interact with CREB.

\section{MATERIALS}

\section{A. Equipment}

Scintillation counter, model LS1710, Beckman ${ }^{1}$

Luminometer, Model 6500, Packard ${ }^{2}$

Laminar flow hood, model B40-112, Baker ${ }^{3}$

Incubator, $5 \% \mathrm{CO}_{2}$ and $3 \% \mathrm{CO}_{2}$, Model 2710, Queue Systems ${ }^{4}$

pH meter, model 240, Corning 5

Speedvac, system SSI, Savant ${ }^{6}$

Microcentrifuge, Eppendorf model 5415C, Baxter ${ }^{7}$

B. Chemicals

Dubecco's Modified Eagle's medium (DMEM), 3201965AJ, GIBCO 8

F10 medium, $320-1550 \mathrm{AJ}^{8}$

Fetal bovine serum (FBS), 200-6000AJ ${ }^{8}$

Horse serum, 200-6050 $\mathrm{AJ}^{8}$

Lipofectin, 8292SA

8-(4-Chlorophenylthio)-cAMP (CPT-cAMP), C3912, Sigma9

Gelatin, porcine, 300 bloom, G25009

n-Butyryl Coenzyme A (butyryl-CoA), B1508

$\mathrm{N}$-, $\mathrm{N}$-Bis(2-hydroxyethyl)-2-amino-ethanesulfonic acid (BES), 391334, Calbiochem

$\left[{ }^{3} \mathrm{H}\right]$ chloramphenicol $\left({ }^{3} \mathrm{H}-\mathrm{Cm}\right)$, NET-928, NEN ${ }^{11}$

Xylenes, 9490-01, Aldrich ${ }^{12}$

Tetramethyl pentadecane (TMPD), T2,280-2 ${ }^{12}$

Dithiothreatol (DTT), D0637 $7^{9}$

Glycylglycine, G2265?

ATP, disodium salt, A6419 ${ }^{9}$

$\mathrm{MgSO}_{4}$ (anhydrous), $\mathrm{M}^{2} 506^{9}$

Luciferin, L68829

$\mathrm{KCl}, \mathrm{P} 4504^{9}$

$\mathrm{KH}_{2} \mathrm{PO}_{4}, \mathrm{P}_{3379^{9}}$

$\mathrm{NaCl}, \mathrm{S} 625^{9}$
$\mathrm{NaH}_{2} \mathrm{PO}_{4}, \mathrm{~S} 751^{9}$

Ehylenediaminetetraacetic acid (EDTA), disodium salt, ED2SS $^{9}$

Scintillation fluid, Betamax, $880020, \mathrm{ICN}^{13}$

C. Cell lines

F9 teratocarcinoma

CA-77 medullary thyroid carcinoma

D. Transfection plasmids-all plasmids were isolated by $\mathrm{CsCl}$ gradient (twice) and purified by a previously described protocol (3)

Bluescript, 212207, Stratagene ${ }^{14}$

RSV-luciferase, provided by Dr. M. Wilkinson, Oregon Health Sciences Univ. (5)

RSV-PKA, provided by Dr. R. Maurer, Univ. of lowa (22)

RSV-WTCREB and RSV-KCREB, constructed by cloning the cDNAs for wild-type CREB (WTCREB) and the mutated CREB (KCREB) into the plasmid RC/RSV, Invitrogen ${ }^{15}(29)$

SS-CAT, contains sequences of the rat somatostatin gene from -71 to +53 placed 5 to the gene for chloramphenicol acetyltransferase (24)

E. Supplies

Tissue culture plates, $25020^{5}$

Scintillation vials, R2554-5

Pipettes, sterile, $2 \mathrm{ml}, \mathrm{P} 4676-2 ; 5 \mathrm{ml}, \mathrm{P} 4676-5 ; 10 \mathrm{ml}$, P4676-10 7

Micropipette tips, sterile, $1-200 \mu \mathrm{l}, 53508-810 ; 200$ $1000 \mu \mathrm{l}, 1040-800, \mathrm{VWR}^{16}$

Eppendorf tubes, $1.5 \mathrm{ml}$, sterile, T5050G, Marsh Biomedical $^{17}$

Tissue culture plate scrapers, T4206-1 ${ }^{13}$

Luminometer vials, 55.484, Sarstedt ${ }^{18}$

\section{PROCEDURE}

A. Preparation of solutions

1. Phosphate buffered saline (PBS): Dissolve $0.2 \mathrm{~g} \mathrm{KCl}$, $0.2 \mathrm{~g} \mathrm{KH}_{2} \mathrm{PO}_{4}, 8.2 \mathrm{~g} \mathrm{NaCl}, 1.1 \mathrm{~g} \mathrm{NaH}_{2} \mathrm{PO}_{4}$ into 900 $\mathrm{ml}$ water, $\mathrm{pH}$ to 7.3 with $\mathrm{HCl}$, bring to $1000 \mathrm{ml}$. autoclave.

2. F9 media: $450 \mathrm{ml}$ DMEM, $50 \mathrm{ml}$ FBS

3. CA-77 media: $230 \mathrm{ml}$ DMEM, $230 \mathrm{ml} \mathrm{F10,25 \textrm {ml }}$ horse serum, $12.5 \mathrm{ml}$ FBS

4. $2 \times$ BES: $50 \mathrm{~m} M$ BES, $280 \mathrm{mM} \mathrm{NaCl}, 1.5 \mathrm{mM}$ $\mathrm{Na}_{2} \mathrm{HPO}_{4}, \mathrm{pH}$ to 6.95 with $\mathrm{NaOH}$.

5. $\mathrm{CaCl}_{2}$ buffer, $0.25 \mathrm{M}$ : dissolve $14.7 \mathrm{~g}$ into $90 \mathrm{ml}$ water, bring volume to $100 \mathrm{ml}$, autoclave.

6. Extraction buffer Dissolve $8.71 \mathrm{~g} \mathrm{~K}_{2} \mathrm{PO}_{4}$ in $400 \mathrm{ml}$ water, $\mathrm{pH}$ to 7.8 with $\mathrm{HCl}$, bring to $500 \mathrm{ml}$. Add DTT to $1 \mathrm{mM}(77.2$ $\mathrm{mg} / 500 \mathrm{ml}$ ) just before use.

7. CPT-cAMP, $200 \mathrm{mM}$ : dissolve $493.8 \mathrm{mg} / 5 \mathrm{ml}$ water, sterile filter.

8. Tris-EDTA (TE) buffer: dissolve $1.21 \mathrm{~g}$ tris base. $0.37 \mathrm{~g}$ EDTA into $900 \mathrm{ml}$ water, $\mathrm{pH}$ to 8.0 with $\mathrm{HCl}$. bring volume to $1000 \mathrm{ml}$, autoclave.

9. Butyryl-CoA, $2.5 \mathrm{mM}$ : dissolve $2.1 \mathrm{mg} / \mathrm{ml}$ water.

10. Tris buffer, $1 \mathrm{M}, \mathrm{pH} 7.4$ : dissolve $121 \mathrm{~g}$ tris base into $900 \mathrm{ml}$ water, $\mathrm{pH}$ to 7.4 with $\mathrm{HCl}$, bring volume to $1000 \mathrm{ml}$, autoclave. 
11. ATP, $20 \mathrm{~m} M$, $\mathrm{pH}$ 7.5: dissolve $12.1 \mathrm{mg} / \mathrm{ml}$ water, $\mathrm{pH}$ to 7.5 by adding $39 \mu \mathrm{l} 1 \mathrm{~N} \mathrm{NaOH} / \mathrm{ml}$ solution.

12. Luciferase buffer: dissolve $2.18 \mathrm{~g}$ glycylglycine, 1.2 $\mathrm{g} \mathrm{MgSO}_{4}$ into $450 \mathrm{ml}$ water, $\mathrm{pH}$ to 7.8 , bring volume to $500 \mathrm{ml}$.

13. Luciferase reaction mix: for each reaction, mix $262.5 \mu$ l luciferase buffer, 87.5 $\mu$ l ATP.

B. Gelatin-coated tissue culture plates: dissolve $0.7 \mathrm{~g}$ gelatin/ $100 \mathrm{ml}$ water, sterile filter. Add 2 to $3 \mathrm{ml} / 100 \mathrm{~mm}$ tissue culture plate, sit at room temperature, $15 \mathrm{~min}$. Remove liquid by aspiration and use immediately. Coated plates cannot be stored for future use.

C. Transfection

1. F9 cells by BES buffer: cells were routinely grown on gelatin-coated tissue culture plates at $37^{\circ} \mathrm{C}$ in $5 \%$ $\mathrm{CO}_{2} ; 3.5 \times 10^{5}$ cells were plated on $10-\mathrm{cm}$ dishes $18 \mathrm{~h}$ before transfection. DNA was mixed in the following amounts: $5 \mu \mathrm{g}$ SS-CAT, $2 \mu \mathrm{g}$ RSV-luciferase, and varying amounts of RSV-PKA, RSV-WTCREB, and RSV-KCREB as indicated. Total DNA in each transfection was $37 \mu \mathrm{g}$, the balance being made up with Bluescript. To these were added $0.5 \mathrm{ml}$ of $\mathrm{CaCl}_{2}$ buffer, followed by $0.5 \mathrm{ml} \mathrm{BES}$ buffer, and incubated at room temperature for $15 \mathrm{~min}$. The mixtures were then added to each tissue culture plate and the plate incubated overnight at $37^{\circ} \mathrm{C}$ in $3 \% \mathrm{CO}_{2}$. The media were removed, the cells washed once with PBS, fresh media added, and the cells placed at $37^{\circ} \mathrm{C}$ in $5 \%$ $\mathrm{CO}_{2}$. The cells were collected $24 \mathrm{~h}$ later.

2. Ca-77 by lipofectin: cells were routinely grown on tissue culture plates at $37^{\circ} \mathrm{C}$ in $5 \% \mathrm{CO}_{2}$. Cells were plated at $5 \times 10^{5} / 6-\mathrm{cm}$ dish $18 \mathrm{~h}$ before transfection. In $1.0 \mathrm{ml}$ serum-free media, the following DNA was added: $2.5 \mu \mathrm{g} \mathrm{SS}-\mathrm{CAT}, 2 \mu \mathrm{g} \mathrm{RSV}$-luciferase, and either RSV-WTCREB or RSV-KCREB as indicated, followed by addition of $30 \mu \mathrm{g}$ lipofectin. The total amount of DNA in each transfection was $30 \mu \mathrm{g}$, the balance being made up with Bluescript. After the cells were rinsed once with serum-free media, $10 \mathrm{ml}$ serum-free media and the lipofectin-DNA mix were added to each tissue culture plate. Serum to normal levels was added after $24 \mathrm{~h}$, followed by addition $6 \mathrm{~h}$ later of CPT-cAMP to a final concentration of 0.2 $\mathrm{m} M$. Cells were harvested $36 \mathrm{~h}$ after addition of the CPT-cAMP.

D. Harvesting of cells: Cells were rinsed twice with $5 \mathrm{ml}$ ice-cold PBS. One milliliter of ice-cold extraction buffer is added to each plate, cells collected with a cell scraper, and placed in an Eppendorf tube. The cells were spun at 4000 $\mathrm{rpm}, 4^{\circ} \mathrm{C}, 5 \mathrm{~min}$ in a microcentrifuge. The supernatent was aspirated, the cells resuspended in $0.1 \mathrm{ml}$ extraction buffer, and lysed by three cycles of freeze-thaw by immersion into dry ice and a $37^{\circ} \mathrm{C}$ water bath. Pellet debris was removed by centrifugation at $15000 \mathrm{rpm}, 4^{\circ} \mathrm{C}, 5 \mathrm{~min}$ in a microcentrifuge, and the supernatent transferred to a new Eppendorf tube. Supernatents could be stored frozen at $-20^{\circ} \mathrm{C}$ for at least $2 \mathrm{wk}$.

E. CAT assay: Preparation of $\left[{ }^{3} \mathrm{H}\right] \mathrm{Cm}$ : determine total amount of label required $(0.2 \mathrm{mCi} /$ tube which is equal to $0.2 \mu \mathrm{l}$ ). Dilute amount needed 1:25 in TE buffer, add 2 vol xylenes, vortex $30 \mathrm{~s}$, microfuge $1 \mathrm{~min}$. Discard xylenes (top layer) and repeat extraction. Remove traces of xylenes by centrifuging under vacuum in speedvac for 5 $\mathrm{min}$. Prepare a mix of reagents. Volumes per reaction are: $\left[{ }^{3} \mathrm{H}\right] \mathrm{Cm}, \quad 5 \mu \mathrm{l}$ $1 M$ tris buffer $\quad 10 \mu \mathrm{l}$ $2.5 \mathrm{mM}$ butyryl CoA $10 \mu \mathrm{l}$ water

$45 \mu$ l (this volume based upon a cell extract volume of $30 \mu \mathrm{l}$.

Total reaction volume is $100 \mu \mathrm{l}$.) Incubate $30 \mu \mathrm{l}$ each cell extract in Eppendorf tubes at $70^{\circ} \mathrm{C}$ for $15 \mathrm{~min}$. Allow to cool on bench, $5 \mathrm{~min}$. Add 70 $\mu$ reagent mix to each sample, vortex, incubate at $37^{\circ} \mathrm{C}$, $2 \mathrm{~h}$. If longer incubations are required due to low activity, place samples in a $37^{\circ} \mathrm{C}$ incubator to inhibit formation of condensation on inside top of tube. Terminate reaction by addition of 2 vol $(200 \mu \mathrm{l})$ TMPD:xylenes, 2:1. Vortex 1 $\mathrm{min}$, sit $5 \mathrm{~min}$, vortex $1 \mathrm{~min}$, microfuge $5 \mathrm{~min}$, and remove $150 \mu \mathrm{l}$ of organic phase (top layer) and place in scintillation vial. Add $4 \mathrm{ml}$ scintillation fluid, vortex, and determine radioactivity in scintillation counter.

F. Luciferase assay: To each tube, add $350 \mu l$ luciferase reaction mix and $10 \mu \mathrm{l}$ extract. Dilute luciferin as needed ( $100 \mu \mathrm{l} /$ reaction) to $0.1 \mathrm{mM}$ by addition of $8 \mu \mathrm{l}$ stock solution to $2 \mathrm{ml}$ water. Place diluted solution in foilwrapped tube to keep it dark. Place samples in carousel and luciferin in the injector. Inject $100 \mu$ luciferin per reaction, count for $10 \mathrm{~s}$.

G. Data analysis: Because the transfection efficiency can vary between tissue culture plates, CAT activity is normalized to luciferase activity for each sample.

\section{DISCUSSION}

We have used these techniques to examine the ability of a mutated CREB, KCREB, to act as a dominant repressor of CREB in vivo. We had previously determined that in gel shift assays, KCREB would block the ability of CREB to bind to the somatostatin CRE (29). By transfecting expression vectors for CREB, KCREB, and a reporter construct which would respond to CREB, the ability of $\mathrm{KCREB}$ to act as an in vivo dominant repressor of CREB could be tested.

The F9 cell line used for these experiments has little CRE response by itself and therefore produces little background activity. Because F9 cells also have a minimal cAMP response even when CREB is transfected into the cells, an additional expression construct for PKA is required to obtain a stimulated CREB response. In Fig. 1, F9 cells transfected with CREB produce a significant increase in activity when cotransfected with PKA. Increasing the amount of CREB produces a further increase in stimulated activity. However, when CREB is cotransfected with an equal amount of the KCREB mutant, the PKA-induced stimulation is blocked. Thus, the KCREB mutant acts as a dominant repressor of CREB function in vivo.

Having identified a tool that can be used to eliminate the activity of CREB in an in vivo situation, we wanted to determine whether it will block an endogenous cAMP-response. The CRE from the somatostatin gene was used for 
these experiments because CREB was originally cloned using the somatostatin CRE as a probe $(12,15)$. Furthermore, CREB can transactivate the somatostatin promoter via the CRE in vivo $(1,9,11)$. However, it has been difficult to get direct evidence that CREB is the endogenous mediator of the CAMP induction of somatostatin. The CA77 cell line expresses CREB and addition of cAMP analogues to the culture medium stimulates transcription of the somatostatin gene. By transfecting KCREB into this cell line, the in vivo role of $C R E B$ in the induction of somatostatin can be assessed.

Both wild type CREB (WTCREB) and KCREB were transfected into CA-77 cells. CAT activity driven by the somatostatin promoter was determined both in unstimulated and cAMP-stimulated cells. The WTCREB produced a modest increase on both basal and stimulated expression (Fig. 2). The KCREB construct had no effect on basal activity. However, stimulated activity was inhibited by $50 \%$. Doubling the amount of transfected KCREB had no further effect on CAT activity.

The mechanism of action of KCREB is to dimerize with the wild-type factor and block its ability to bind the CRE. If other factors can dimerize with KCREB, these may also be inhibited. Thus, although the $50 \%$ inhibition of activity indicates that the somatostatin promoter is sensitive to $\mathrm{KCREB}$, there may be factors in addition to CREB responsible for the KCREB-sensitive portion of the induction. The fact that approximately $50 \%$ of the induction was insensitive to KCREB suggests that factors in addition to CREB, which do not dimerize with CREB, also participate in the cAMP-induction of the somatostatin promoter.

The expression of specific trans-acting factors and cisacting sequences in cell lines by means of transfection

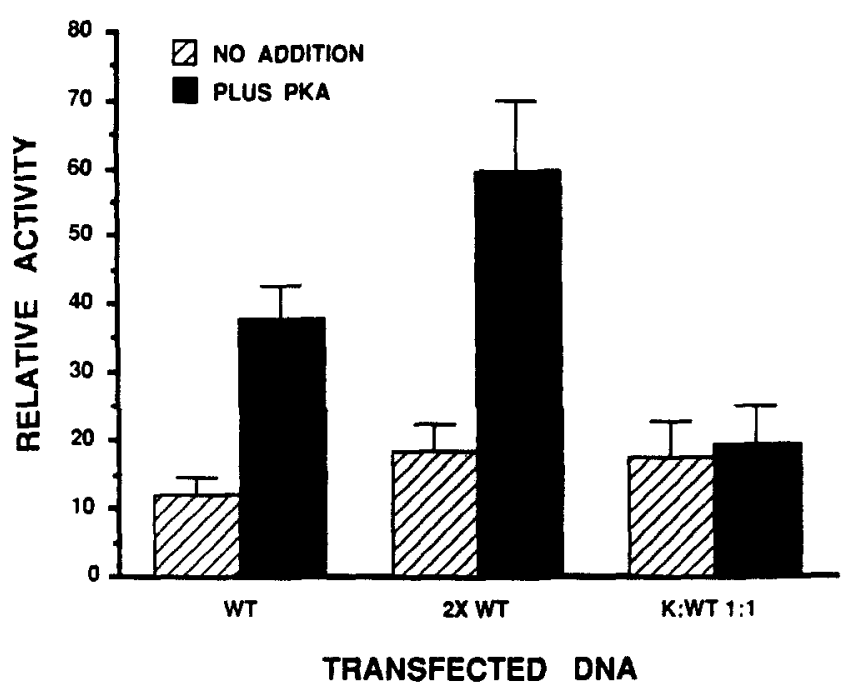

FIC. 1. KCREB blocks the protein kinase A-dependent induction of transcription by wild-type CREB. F9 cells were co-transfected with SS-CAT $(5 \mu \mathrm{g})$, RSV-Luc $(2 \mu \mathrm{g})$, and the expression vectors RSV-PKA, RSVWTCREB, and RSV-KCREB. Data are normalized to control activity and shown as the mean and standard error of five independent experiments. WT, WTCREB $(10 \mu \mathrm{g}) ; 2 X$ WT, WTCREB $(20 \mu \mathrm{g}) ; K: W T ~ 1: 1, \mathrm{KCREB}(10$ $\mu \mathrm{g})$, and WTCREB $(10 \mu \mathrm{g})$.

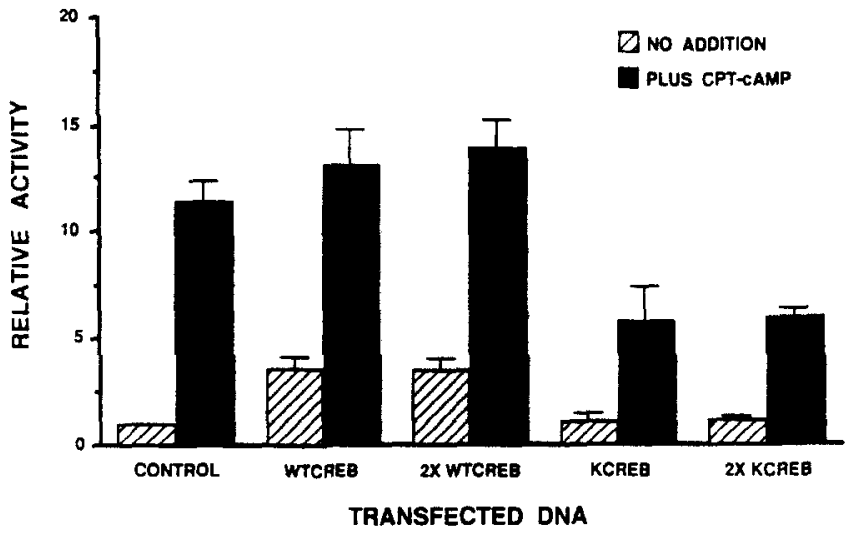

FIG. 2. KCREB partially inhibits the cAMP-mediated induction of the somatostatin promoter in CA-77 cells. CA-77 cells were co-transfected with SS-CAT $(5 \mu \mathrm{g})$, RSV-Luc $(1.5 \mu \mathrm{g})$, and the expression vectors RSVWTCREB and RSV-KCREB ( 10 or $20 \mu \mathrm{g}$, as indicated). Values are normalized to control activity and represent the mean and standard error of three independent experiments.

allows many questions to be addressed that are difficult to approach by in vitro analyses. The ability of factors 10 transactivate particular enhancer sequences, to respond to particular second messenger pathways and the identification of functional domains within the factors are questions that have all been addressed by transfection into cell lines. Determination of the cis-acting nucleotide sequences required for a particular response is also readily approachable by transfection into cell lines. Through the use of appropriate cell lines, transfection experiments dissecting neuropeptide gene expression has produced much information on their mechanism of control and should continue to do so in the future.

\section{REFERENCES}

1. Andrisani, O. M.; Dixon, J. E. Somatostatin gene regulation. Ann. Rev Physiol. 52:793-806; 1990.

2. Andrisani, O. M.; Hayes, T. E.; Roos, B., et al. Identification of the promoter sequences involved in the cell specific expression of the rat somatostatin gene. Nucleic Acids Res. 15:5715-5728: 1987.

3. Chen, C.; Okayama, H. Calcium phosphate-mediated gene transfer: a highly efficient transfection system for stably transforming cells with plasmid DNA. Biotechniques 6:632-638; 1988.

4. Comb, M.; Birnbirg, N. C.; Seasholt2, A., et al. A cyclic AMP- and phorbol ester-inducible DNA element. Nature 323:353-356; 1986.

5. de Wet. J. R.; Wood, K. V.; De Luca, M., et al. Firefly luciferase gene: structure and expression in mammalian cells. Mol. Cell. Biol. $7: 725-$ $737 ; 1987$

6. Delegeane, A. M.; Ferland, L. H.; Mellon, P. L. Tissue-specific enhancer of the human glycoprotein hormone $\alpha$-subunit gene: dependance on cyclic AMP-inducible elements. Mol. Cell. Biol, 7:3994-4002; 1987.

7. Deutsh, P. J.; Hoeffler, J. P.; Jameson, J. L., et al. Cyclic AMP and phorbol ester-stimulated transcription mediated by similar DNA elements that bind distinct proteins. Proc. Natl. Acad. Sci. USA 85:7922-7926; 1988.

8. Deutsh, P. J.; Hoeffler, J. P.; Jameson, J. L., et al. Structural determinants for transcriptional activation by cAMP-responsive DNA elements. J. Biol. Chem. 263:18466-18472; 1988.

9. Dwarki, V. J.; Montminy, M.; Verma, I. M. Both the basic region and the 'leucine zipper' domain of the cyclic AMP response element binding (CREB) protein are essential for transcriptional activation. EMBO J. 9:225-232: 1990 . 
10. Eiden, L. E.; Hotchkiss, A. J. Cyclic adenosine monophosphate regulates vasoactive intestinal polypeptide and enkephalin biosynthesis in cultured bovine chromaffin cells. Neuropeptides 4:1-9; 1983.

11. Gonzalez, G. A.; Montminy, M. R. Cyclic AMP stimulates somatostatin gene transcription by phosphorylation of CREB at serine 133. Cell 59:675-680; 1989.

12. Gonzalez, G. A.; Yamamoto, K. K.; Fischer, W. H., et al. A cluster of phosphorylation sites on the cyclic AMP regulated nuclear factor CREB predicted by its sequence. Nature 337:749-752; 1989.

13. Hai, T.; Liu, F.; Coukos, W. J., et al. Transcription factor ATF cDNA clones: an extensive family of leucine zipper proteins able to selectively form DNA-binding heterodimers. Genes Dev. 3:2083-2090; 1989.

14. Hayakawa, Y.; Obata, K.; Itoh, N., et al. Cyclic AMP regulation of pro-vasoactive intestinal polypeptide/PHM-27 synthesis in human neuroblastoma cells. J. Biol. Chem. 259:9207-9211; 1984.

15. Hoeffler, J. P.; Meyer, T. E.; Yun, Y., et al. Cyclic AMP-responsive DNAbinding protein: structure based on a cloned placental cDNA. Science 242:1430-1433; 1988.

16. Ivashkiv, L. B.; Liou, H.-C.; Kara, C. J., et al. MXBP/CRE-BP2 and c-jun form a complex which binds to the cyclic AMP, but not the 12-o-tetradecanoylphorbol-13-acetate, response element. Mol. Cell. Biol. 10:1609$1621 ; 1990$.

17. Jameson, J. L.; Albanese, C.; Habener, J. F. Distinct adjacent protein-binding domains in the glycoprotein hormone $\alpha$ gene interact with a cAMPresponsive enhance. J. Biol. Chem. 264:16190-16196; 1989.

18. Landschultz, W. H.; Johnson, P. F.; McKnight, S. L. The leucine zipper: a hypothetical structure common to a new class of DNA binding proteins. Science 240:1759-1764; 1988.

19. Lee, C. Q.; Yun, Y.; Hoeffler, J. P., et al. Cyclic-AMP-responsive transcriptional activation of CREB-327 involves interdependent phosphorylated subdomains. EMBO J. 9:4455-4465; 1990.

20. Macgregor, P. F.; Abate, C.; Curran, T. Direct cloning of leucine zipper proteins: Jun binds cooperatively to the CRE with CRE-BP1. Oncogene $5: 451-458 ; 1990$.

\footnotetext{
${ }^{1}$ Beckman Instruments, Inc., Fullerton, CA

${ }^{2}$ Packard Instrument Co., Downers Grove, IL

${ }^{3}$ The Baker Co., Sanford, ME

${ }^{4}$ Queue Systems, Inc., Parkersburg, WV

${ }^{5}$ Corning Inc., via Fischer Scientific, Pittsburgh, PA

${ }^{6}$ Savant Instruments, Inc., Farmingdale, NY

${ }^{7}$ Baxter Diagnostics, Inc., McGraw Park, IL.

${ }^{8}$ GIBCO BRL, Gaithersburg, MD

${ }^{9}$ SIGMA Chemical Co., St. Louis, MO
}

21. Maekawa, T.; Sakura, H.; Kanei-Ishii, C., et al. Leucine zipper structure of the protein CRE-BPI binding to the cyclic AMP response element in brain. EMBO J. 8:2023-2028; 1989.

22. Maurer, R. A. Both isoforms of the cAMP-dependent protein kinase catalytic subunit can activate transcription of the prolactin gene. J. Biol. Chem. 264:6870-6873; 1989.

23. Montminy, M. R.; Low, M. J.; Tapia-Arancibia, L., et al. Cyclic AMP regulates somatostatin mRNA accumulation in primary diencephalic cul. tures and in transfected fibroblast cells. J. Neurosci 6:1171-1176; 1986.

24. Montminy, M. R.; Sevarino, K. A.; Wagner, J. A., et al. Identification of a cyclic-AMP-responsive element within the rat somatostatin gene. Proc. Natl. Acad. Sci. USA 83:6682-6686; 1986.

25. O'Shea, E. K.; Rutkowski, R.; Kim, P. S. Evidence that the leucine zipper is a coiled-coil. Science 243:538-542; 1989.

26. Short, J. M.; Wynshaw-Boris, A.; Short, H. P., et al. Characterization of the phosphoenolpyruvate carboxykinase (GTP) promoter-regulatory region. J. Biol. Chem. 261:9721-9726; 1986.

27. Silver, B. J.; Bokar, J. A.; Virgin, J. B., et al. Cyclic AMP regulation of the human $\alpha$-glycoprotein gene is mediated by an 18-base pair element. Proc. Natl. Acad. Sci. USA 84:2198-2202; 1987.

28. Tsukada, T.; Fink, J. S.; Mandel, G., et al. Identification of a region in the human vasoactive intestinal peptide gene responsible for regulation by cyclic AMP. J. Biol. Chem. 262:8743-8747; 1987.

29. Walton, K. M.; Rehfuss, R. P.; Chrivia, J. C., et al. A dominant repressor of cyclic adenosine 3',5'-monophosphate (cAMP)-regulated enhancer-binding protein activity inhibits the CAMP-mediated induction of the somatostatin promoter in vivo. Mol. Endocrinol. 6:647-655; 1992.

30. Weaver, C. A.; Gordon, D. F.; Kissel, M. S., et al. Isolation and complete nucleotide-sequence of the gene for bovine parathyroid-hormone. Gernt 28:319-329; 1984.

31. Wynshaw-Boris, A.; Lugo, T. G.; J. M., S., et al. Identification of a cAMP regulatory region in the gene for rat cytosolic phosphoenolpyruvate car boxykinase (GTP). J. Biol. Chem. 259:12161-12169; 1984.

\footnotetext{
${ }^{10}$ Calbiochem, La Jolla, CA

11 New England Nuclear, Boston, MA

12 Aldrich Chemical Co., Milwaukee, WI

13 ICN Biochemicals Inc., Costa Mesa, CA

${ }^{14}$ Stratagene, Inc., La Jolla, CA

15 Invitrogen Corp., San Diego, CA

${ }^{16}$ VWR Scientific, Chicago, IL

17 Marsh Biomedical Products Inc., Rochester, NY

${ }^{18}$ Sarstedt, Newton, NC
} 